\title{
Exploring Anorganic Bovine Bone Granules as Osteoblast Carriers for Bone Bioengineering: A Study in Rat Critical-Size Calvarial Defects
}

\author{
Willian F. ZAMBUZZI ${ }^{1,2}$ \\ Gustavo V. O. FERNANDES ${ }^{3}$ \\ Flávia G. IANO ${ }^{4}$ \\ Mileni da S. FERNANDES ${ }^{4}$ \\ José Mauro GRANJEIRO ${ }^{2}$ \\ Rodrigo Cardoso OLIVEIRA ${ }^{4}$
}

\author{
${ }^{1}$ Multidisciplinary Laboratory of Dental Research (LAMP), Heath Sciences School, \\ UNIGRANRIO - University of Grande Rio, Duque de Caxias, RJ, Brazil \\ ${ }^{2}$ Bioengineering/DIPRO, INMETRO - National Institute of Metrology, \\ Standardization and Industrial Quality, Duque de Caxias, RJ, Brazil \\ ${ }^{3}$ Clinical Research Unit, Antônio Pedro University Hospital (HUAP), \\ UFF - Federal Fluminense University, Niterói, RJ, Brazil \\ ${ }^{4}$ Laboratory of Biochemistry, Department of Biological Sciences, Bauru Dental School, \\ USP - University of São Paulo, Bauru, SP, Brazil
}

\begin{abstract}
It is known that current trends on bone bioengineering seek ideal scaffolds and explore innovative methods to restore tissue function. In this way, the objective of this study was to evaluate the behavior of anorganic bovine bone as osteoblast carrier in critical-size calvarial defects. MC3T3-E1 osteoblast cells ( $1 \times 10^{5}$ cells/well) were cultured on granules of anorganic bovine bone in 24 -well plates and after $24 \mathrm{~h}$ these granules were implanted into rat critical-size calvarial defects (group Biomaterial + Cells). In addition, other groups were established with different fillings of the defect: Blood Clot (negative control); Autogenous Bone (positive control); Biomaterial (only granules) and Cells (only MC3T3-E1 cells). After 30 days, the animals were euthanized and the calvaria were technically processed in order to allow histological and morphometric analysis. It was possible to detect blood vessels, connective tissue and newly formed bone in all groups. Particularly in the Biomaterial + Cells group, it was possible to observe a profile of biological events between the positive control group (autogenous bone) and the group in which only anorganic bovine granules were implanted. Altogether, the results of the present study showed that granules of anorganic bovine bone can be used as carrier to osteoblasts and that adding growth factors at the moment of implantation should maximize these results.
\end{abstract}

Key Words: bone bioengineering, osteoblasts, rat critical-size calvarial defects, hydroxyapatite.

\section{INTRODUCTION}

Bone bioengineering has emerged as a potential field in regenerative medicine as a support for the reconstruction of critical-size bone defects generated in different ways, such as bone tumor resection or bone loss due to trauma (1). There are several approaches to bone tissue engineering, but all involve one or more of the following key ingredients: harvested cells, recombinant signaling molecules, and three-dimensional
(3D) matrices. In this way, several graft materials have been used for the restoration of these defects (1-5). In general, a graft ideally needs to promote bone growth in order to restore a functional tissue. Over the last years, some advances have been made regarding the scaffolds in dentistry, making these biomaterials indispensable for the professionals in the areas of bucomaxillofacial, paraendodontic, orthognathic and implant surgeries. Among the candidate biomaterials to be scaffolds for recovering bone losses, calcium phosphate (Ca-P)- 
derivatives have gained acceptance among professionals of the medical and dental fields $(3,6)$.

Calcium phosphate materials can be found in nature (hydroxyapatite - inorganic portion of healthy bones) or can be synthesized by precipitation methods using chemical reagents. In addition, this research group has centered efforts to investigate the osteo-properties of bovine bone as potential scaffold (7-9) and also for understanding the osteoblast biology $(3,10-13)$. Thus, these biomaterials represent an important alternative to autogenous and allogenous grafts because they have biocompatibility, due to appropriate mechanical and chemical treatments, and osteoconduction property due to its architecture and structural surface, characteristics similar to original human bone. It is known that these biomaterials enhance cell proliferation, migration and maturation into the repairing tissue.

Because Stephan et al. (14) have shown that cultured rat osteoblasts interact with the surface of anorganic porous bone, promoting cell adhesion, proliferation and maturation, the present study investigated the biological response of this combination (anorganic bovine bone and osteoblast cells) in criticalsize calvarial defects.

\section{MATERIAL AND METHODS}

\section{Material}

The tested material was macrogranular porous anorganic bone (1-2 mm granules) of bovine medular bone origin, deproteinized at $100^{\circ} \mathrm{C}$ (Gen-Ox; Baumer S.A., Mogi Mirim, SP, Brazil).

\section{Cell Culture}

MC3T3-E1, a calvaria mouse pre-osteoblast cell line, was obtained from ATCC (American Type Culture Collection; Manassas, VA, USA) and grown at $37^{\circ} \mathrm{C}$ in $\alpha$-MEM (Invitrogen, Carlsbad, CA, USA) medium supplemented with $10 \%$ fetal bovine serum (FBS) (Invitrogen), $100 \mathrm{U} / \mathrm{mL}$ of penicillin, and $100 \mu \mathrm{g} / \mathrm{mL}$ of streptomycin in a humidified $5 \% \mathrm{CO}_{2}$ atmosphere.

\section{Experimental Design}

At a confluent stage, the cells were trypsinized and seeded on granules of bovine anorganic bone. After $24 \mathrm{~h}$, these granules containing cells were implanted into critical-size calvarial defects in rats. For comparison purposes, the groups were divided as follows: Blood Clot (negative control); Autogenous Bone (positive control); Biomaterial; Cells; Biomaterial + Cells.

\section{Surgical Procedures}

This research was submitted to and approved by the Committee of Ethics in Education and Research in Animals of Bauru Dental School, University of São Paulo (Process \#19/2006).

Shaving and incision were performed at the frontal-parietal region of each rat under general intramuscular anesthesia with xylazine hydrochloride (Anasedan; Vetbrands, Paulínia, SP, Brazil) and ketamine hydrochloride (Dopalen; Vetbrands) in a 1:1 proportion. A perforation through the whole thickness of the diploe was performed with a $8 \mathrm{~mm}$ external diameter surgical trephine (Dentoflex, São Paulo, SP, Brazil) and continuous irrigation with saline solution (7). The critical-size defect in the control group received only a blood clot while the test group defect was filled with the biomaterial mixed with blood.

\section{Collection of Specimens and Histotechnical Processing}

In all experimental periods, the rats were euthanized with an anesthetic overdose and the skulls were removed and immediately fixed in $10 \%$ buffered formaldehyde during 1 week. The skulls were then radiographed using optic plates with the following parameters: $70 \mathrm{kVp}, 10 \mathrm{mAs}, 40 \mathrm{~cm}$ film-focus distance and $0.26 \mathrm{~s}$ exposure time. The images were evaluated using the Digora system (Sordex Orion Corporation, Helsinki, Finland) to follow the positioning of the material inside the bone defect. The specimens were demineralized in EDTA, $\mathrm{pH}$ 7.2, (Merck KGaA, Darmstadt, Germany) for approximately 2 months with weekly solution changes. After demineralization, the specimens were dehydrated in ethanol, cleared in xylol and embedded in Histosec (Merck KGaA), following the classical steps of histological procedure. Semi-serial sections of $5 \mu \mathrm{m}$ thickness in a lateral-lateral direction were obtained and stained with hematoxylin and eosin.

\section{Histological and Morphometric Analysis}

An Axioskop 2 binocular microscope (Carl Zeiss, 
Oberkochen, Germany) was used to examine and evaluate the histological cuts according to new bone formation in the defect and also around biomaterial particles, presence and quality of the inflammatory infiltrate, intensity of the angiogenesis and occurrence of fibrosis between particles and/or in the defect space. The same microscope was used to obtain the photomicrographs (magnification of $\times 10$ ), and contained a photographic camera and a MC200 software chip. The osteoconductive capacity of the biomaterial was evaluated verifying new bone formation directly on the surface of particles. Histological sections (coronal cuts) were stained with hematoxylin-eosin for histomorphometric analysis. This method was used to evaluate the volume density of the main structures of interest: newly formed bone, connective tissue and residual biomaterials. The Image Pro Plus ${ }^{\circledR} 4.5$ (Media Cybernetics, Silver Spring, MD, USA) software was used to count point [system of 100 points] (15) through a grid placed over each picture. Thus, an estimative of the volume density was obtained.

The obtained data were evaluated by ANOVA and Tukey's post-test with a significance level of 5\% using the InStat v3.01 statistical program (GraphPad Inc., San Diego, CA, USA). Then, graphs were created according to the analyzed data (Prism v. 5.0; GraphPad Inc.).

\section{RESULTS}

\section{Histologic Analysis at 30 Days}

Blood Clot Group (negative control): connective tissue was observed occupying the defect space (Fig. 1A) and was composed by collagen fibers, fibroblastlike cells and blood vessels (Fig. 1B). No inflammatory infiltrate was found. A discrete amount of new bone formed at the border of the defect was observed.

Autogenous Bone Group (positive control): in this group it was noticed new bone formation in direct contact with the implanted autogenous bone particles. In the central area of the defect (Fig. 1C), there was an advanced bone repair process. There was a small amount of connective tissue between the implanted autogenous bone particles and bone and tegument (Fig. 1D). No inflammatory cell infiltrate was observed.

Biomaterial Group: little new bone formation was observed in direct contact with some implanted biomaterial particles and also at the border of the defect. The central area of the defect was filled with biomaterial granules and connective tissue (Fig. 1E), which was composed primarily by fibroblast-like cells and collagen fibers surrounding the implanted biomaterial granules. A suggestive area of tissue growing into biomaterial pores was also observed, including new bone formation (Fig. 1F).

Cells Group: this group had a result similar to the negative control (Blood Clot group), with connective tissue formation (Fig. 1G), composed primarily of fibroblast-like cells, blood vessels and collagen fibers (Fig. 1H) of the central defect. A discrete amount of new bone formed at the border of the defect could be seen.

Biomaterial + Cells Group: histological findings in this group were similar to the Biomaterial group. New bone formation at the border of the defect and close to some implanted biomaterial particles was observed (Fig. 1I). The central defect area was filled with biomaterial particles and connective tissue. Biomaterial pores were occupied by cells, connective tissue, suggesting migration and cellular invasion (Fig. 1J). Some samples exhibited new bone formation inside the pores of the implanted biomaterial particles.

\section{Histomorphometric Analysis at 30 Days}

New Bone Formation: no statistically significant difference $(\mathrm{p}>0 ; 05)$ was found among the groups, except for the Autogenous Bone Group (positive control), which had better results and differed significantly $(\mathrm{p}<0.05)$ from all other groups (Fig. 2A).

Connective Tissue: the Autogenous Bone group differed significantly $(p<0.05)$ from the Biomaterial and Cells groups. The Biomaterial + Cells group had a lower volume density of connective tissue when compared with the control groups, suggesting a better response of the local tissue (Fig. 2B).

Biomaterial: the degradability rate of the biomaterial among the groups was not statistically significant at 30 days (Fig. 2C).

\section{DISCUSSION}

The last two decades have witnessed a major breakthrough in the field of regenerative medicine and tissue engineering (16). Together with advancements in this new field came the emergence of the concept of new materials mimicking the host tissue, i.e. biomaterials, which present similar characteristics to the target tissue of the host/receiver (17). In this way, new biomaterials and alternatives have been studied for application in 

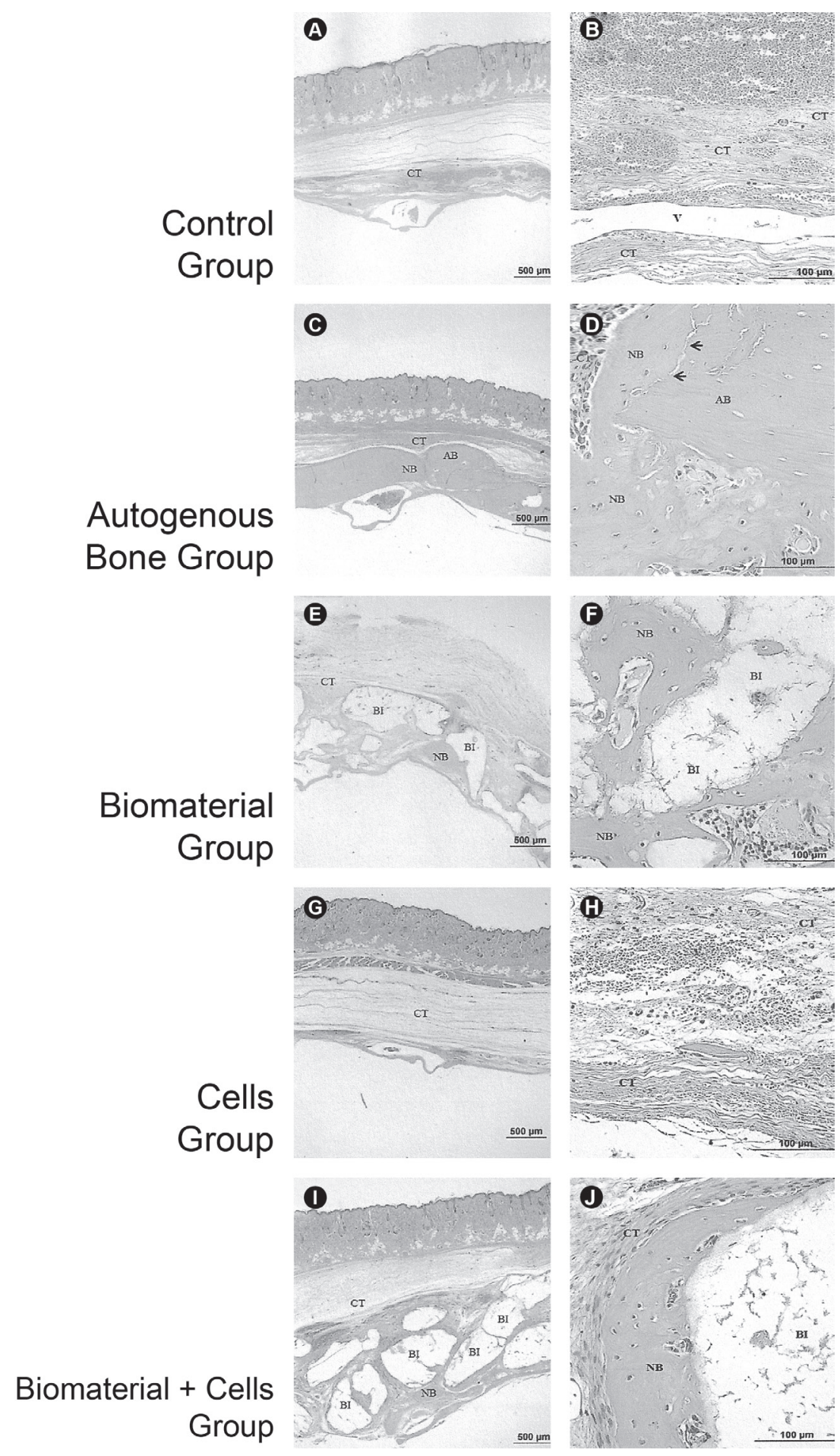

Figure 1. Photomicrographs (Hematoxylin and eosin stain) showing tissue response at 30 days. In the Control Group (A, B), it can be seen connective tissue and blood vessels on reactionary tissue into bone defect. Autogenous bone group $(\mathrm{C}$, D) shows clearly new bone surrounding pieces of native bone into bone defect. In the Biomaterial group (E, F), it can be observed new bone and connective tissue close to biomaterial particles and filling the pores. In the Cells group $(\mathrm{G}, \mathrm{H})$ it is observed connective tissue. In the Biomaterial + Cells group (I, J) it is possible to see new bone and connective tissue close to biomaterial and filling the pores. Note: In the Biomaterial + Cells group, MC3T3-E1 osteoblast cells (1x105 cells/well) were cultured on granules of anorganic bovine bone in 24-well plates and after $24 \mathrm{~h}$ these granules were implanted into rat critical-size calvarial defects. AB: autogenous bone. BI: biomaterial. CT: connective tissue. NB: new bone. V: Blood vessel. 
medicine and dentistry. In this scenario, our research group has made an effort to develop a biomaterial of bovine origin as an option to other commercial bone graft materials (8). In addition, the use of these biomaterials as potential scaffolds for tissue engineering has been proposed (9).

Over the last decade, bovine bone presented an option for the development of biomaterial because its structure and composition are similar to natural human bone (18). Regarding the biological model used in this study, it was seen that critical-size calvarial defects have been widely used to assess the osteoconductive/ osteoinductive potential of new biomaterials (2). Previous studies of our research group $(4,5)$ have evaluated these biomaterials implanted in rat subcutaneous tissue in order to evaluate their biocompatibility. In the present study, it was decided to explore rat critical-size calvaria defects based on bone bioengineering aspects, as it is able to promote bone new formation (19).

It is very important to mention that the present findings are similar to those described in the literature, as new bone formation was greater in the group of autogenous bone graft compared with the other groups $(2,20)$. However, it was found little bone tissue formation from the edges of the defect and good biocompatibility of implanted biomaterials, with the presence of connective tissue surrounding the particles within the pores of the biomaterial. Unlike the organic portion (collagen type I + non-collagenous proteins), the inorganic material (hydroxyapatite) remains in the defect for a longer period before being completely resorbed and replaced (7). This was confirmed in the present study by the histological analysis. Another noteworthy detail revealed by the obtained results is the osteoconductive capacity of the inorganic bovine bone, either alone or together with osteoblasts, similar to that described in the literature (8).
The combination biomaterial + cells and biomaterial + cells + growth factors have been studied recently. However, a recent study reported no significant improvement after the addition of cells (osteoblasts and osteoprogenitor cells) and/or growth factors when compared with the biomaterial alone (21), results that are similar to the present ones. Moreover, most studies in the literature have shown that the addition of cells, in combination or not with growth factors and transported by a biomaterial may favor the process of bone formation (22). Some studies have reported an increase in bone formation, accelerated by these components (cells and growth factors) in the initial period or shorter (1-2 weeks) (23). Probably for this reason, such difference was not observed in the Biomaterial + Cells group, since the evaluation period was 30 days.

In this work, the challenge was to evaluate anorganic bovine granules as carrier of osteoblasts. However, both Biomaterial and Biomaterial + Cells groups presented similar behavior: in both groups, it was possible to verify cells and new bone formation into natural pores of the granules, this last similar to those described in the literature (22). These results are interesting because these materials can be used as scaffold to osteoblasts in addition to promoting the recruitment of cells from the host tissue $(22,23)$. In fact, providing the recruitment of specific cells, such as osteoprogenitor cells, is also one of the most important and decisive events in order to restore a new tissue (23). Also similar results were found in this work, once there was formation of bone tissue within the pores of the material (Biomaterial and Biomaterial + Cells groups). Perhaps, the combination of biomaterial with osteoprogenitor cells with some growth factors, such as bone morphogenetic proteins (BMPs), could result in similar biological behavior to those found in response to


Figure 2. Histomorphometric analysis. Images acquired from histological sections illustrating some biological features, as follows: (A) Volume density of connective tissue showing statistically significant differences; (B) Volume density of new bone formation showing statistically significant differences; (C) Volume density of residual biomaterial. Note: ${ }^{*} \mathrm{p}<0.05 ; * * \mathrm{p}<0.01 ; * * * \mathrm{p}<0.001$ 
autogenous bone graft. It is reasonable to suggest that the most common approach involves seeding highly porous biodegradable matrices (or scaffolds), in the shape of the desired bone, with cells and signaling molecules (e.g., protein growth factors), then culturing and implanting the scaffolds into the defect to induce and direct the growth of the new bone. In order to clarify this issue, further studies are required in this direction, testing a spectrum of biomolecules.

Altogether, the results of the present study showed that granules of anorganic bovine bone can be used as carrier to osteoblasts and that adding growth factors at the moment of implantation should maximize these results.

\section{RESUMO}

Sabe-se que uma das atuais tendências na bioengenharia óssea é procurar um carreador ideal e explorar métodos inovadores para restaurar a função do tecido. Desta forma, nosso objetivo foi avaliar o comportamento do osso bovino inorgânico como carreador de osteoblastos em defeitos ósseos de tamanho crítico em calvária de ratos. Osteoblastos da linhagem MC3T3-E1 (1x10 células/poço) foram cultivadas em grânulos de osso bovino inorgânico sob placas de 24 poços e após 24 h esses grânulos foram implantados em defeitos ósseos de tamanho crítico em calvária de ratos. Além deste grupo experimental (Biomaterial + Células), foram estabelecidos outros grupos com diferentes preenchimentos do defeito crítico: coágulo sanguíneo (controle negativo); osso autógeno (controle positivo); Biomaterial (apenas grânulos) e Células (apenas células MC3T3-E1). Após 30 dias, os animais foram eutanasiados e as calvárias foram processadas histotecnicamente, a fim de permitir a análise histológica e morfometria. Nossos resultados mostraram que em todos os grupos avaliados foi possível detectar vasos sanguíneos, tecido conjuntivo e osso neoformado. Em especial para o grupo tratado com Biomaterial + Células, foi possível observar um perfil de eventos biológicos intermediário ao grupo controle positivo (osso autógeno) e o grupo de biomaterial (apenas grânulos inorgânico bovino). Ao todo, nossos resultados mostraram que os grânulos de osso bovino inorgânico podem ser usados como carreador de osteoblastos e que a adição de fatores de crescimento no momento em que ocorre o implante deve maximizar os resultados.

\section{ACKNOWLEDGEMENTS}

The authors thank the technical collaboration of Danielle Santi Ceolin and Patrícia de Sá Mortágua Germino (Laboratory of Histology), and student Jaqueline Caetano Faria for skillfull technical assistance.

\section{REFERENCES}

1. Zambuzzi WF, Coelho PG, Alves GG, Granjeiro JM. Intracellular signal transduction as a factor in the development of "smart" biomaterials for bone tissue engineering. Biotechnol Bioeng 2011;108:1246-1250.
2. Accorsi-Mendonça T, Zambuzzi WF, Bramante CM, Cestari TM, Taga R, Sader M, et al.. Biological monitoring of a xenomaterial for grafting: an evaluation in critical-size calvarial defects. J Mater Sci Mater Med 2011;22:997-1004.

3. Zambuzzi WF, Ferreira CV, Granjeiro JM, Aoyama H. Biological behavior of pre-osteoblasts on natural hydroxyapatite: a study of signaling molecules from attachment to differentiation. J Biomed Mater Res A 2011;97:193-200.

4. Oliveira RC, Menezes R, Cestari TM, Taga EM, Taga R, Buzalaf MA, et al.. Tissue response to a membrane of demineralized bovine cortical bone implanted in the subcutaneous tissue of rats. Braz Dent J 2004;15:3-8.

5. Zambuzzi WF, Oliveira RC, Pereira FL, Cestari TM, Taga R, Granjeiro JM. Rat subcutaneous tissue response to macrogranular porous anorganic bovine bone graft. Braz Dent J 2006;17:274-278.

6. Conz MB, Granjeiro JM, Soares GA. Hydroxyapatite crystallinity does not affect the repair of critical size bone defects. J Appl Oral Sci 2011;19:337-342.

7. Oliveira RC, Oliveira FHG, Cestari TM, Taga R, Granjeiro JM. Morphometric evaluation of the repair of critical-size defects using demineralized bovine bone and autogenous bone grafts in rat calvaria. Clin Oral Implants Res 2008;19:749-754.

8. Sanchez RSL, Oliveira RC, Zambuzzi WF, Takamori ER, Cestari TM, Taga R, et al.. Histomorphometric and radiographic monitoring the repair of critical defects in skulls of rats completed with combination of medular bovine bone plus BMP. Innov Implant J 2009;4:32-38.

9. Gasque KCS, Correa AM, Cestari TM, Taga R, Oliveira RC, Zambuzzi WF, et al.. Collagenic matrix from bovine tendon as a potential biomaterial for tissue bioengineering. Innovations Implant Journal 2011;6:16-20.

10. Zambuzzi WF, Granjeiro JM, Parikh K, Yuvaraj S, Peppelenbosch MP, Ferreira CV. Modulation of Src activity by low molecular weight protein tyrosine phosphatase during osteoblast differentiation. Cell Physiol Biochem 2008;22:497-506.

11. Zambuzzi WF, Bruni-Cardoso A, Granjeiro JM, Peppelenbosch MP, de Carvalho HF, Aoyama H, et al.. On the road to understanding of the osteoblast adhesion: cytoskeleton organization is rearranged by distinct signaling pathways. J Cell Biochem 2009;108:134-144.

12. Milani R, Ferreira CV, Granjeiro JM, Paredes-Gamero EJ, Silva RA, Justo GZ, et al.. Phosphoproteome reveals an atlas of protein signaling networks during osteoblast adhesion. J Cell Biochem 2010;109:957-966.

13. Zambuzzi WF, Oliveira RC, Subitoni BL, Menezes R, Taga R, Granjeiro JM. Biological monitoring of a promissory xenogenic pin for biomedical applications: a preliminary intraosseous study in rats. Clin Oral Implants Res 2012;23:367-372.

14. Stephan EB, Jiang D, Lynch S, Bush P, Dziak R. Anorganic bovine bone supports osteoblastic cell attachment and proliferation. J Periodontol 1999;70:364-369.

15. Carvalho ACB, Henriques HN, Pantaleão JAS, Pollastri CE, Fernandes GVO, Granjeiro JM, et al.. Bone tissue histomorphometry in castrated rats treated with tibolone. J Bras Patol Med Lab 2010;46:235-243.

16 Dimitriou R, Jones E, McGonagle D, Giannoudis PV. Bone regeneration: current concepts and future directions. BMC Med 2011;31:66-76.

17. Lutolf MP, Weber FE, Schmoekel HG, Schense JC, Kohler T, Müller R, et al.. Repair of bone defects using synthetic mimetics of collagenous extracellular matrices. Nat Biotechnol 2003;21:513518.

18. Nakashima M, Reddi AH. The application of bone morphogenetic proteins to dental tissue engineering. Nat Biotechnol 2003;21:10251032. 
19. Ivanovski S, Hamlet S, Retzepi M, Wall I, Donos N. Transcriptiona profiling of "guided bone regeneration" in a critical-size calvarial defect. Clin Oral Implants Res 2011;22:382-389.

20. Kwan MD, Sellmyer MA, Quarto N, Ho AM, Wandless TJ, Longaker MT. Chemical control of FGF-2 release for promoting calvarial healing with adipose stem cells. J Biol Chem 2011;286:11307-11313.

21. Paulo A de O, Castro-Silva II, Oliveira DF, Machado ME, Bonetti-Filho I, Granjeiro JM. Repair of critical-size defects with autogenous periosteum-derived cells combined with bovine anorganic apatite/collagen: an experimental study in rat calvaria. Braz Dent J 2011;22:322-328.
22. Notodihardjo FZ, Kakudo N, Kushida S, Suzuki K, Kusumoto K Bone regeneration with BMP-2 and hydroxyapatite in critical-size calvarial defects in rats. J Craniomaxillofac Surg 2012;40:287291.

23. Monteiro BS, Del Carlo RJ, Argôlo-Neto NM, Nardi NB, Carvalho PH, Bonfá Lde P, et al.. Association of mesenchymal stem cells with platelet rich plasma on the repair of critical calvarial defects in mice. Acta Cir Bras 2012;27:201-209.

Received March 3, 2012 Accepted May 22, 2012 